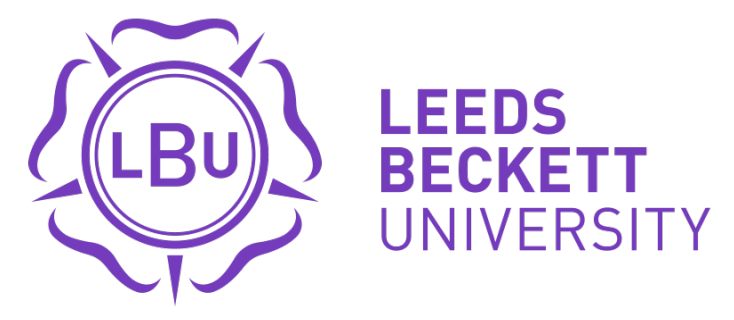

Citation:

Ricci, E and Galbraith, SE and Kipar, A (2015) Pilot study with a murine model to further dissect the pathogenesis of japanese encephalitis. Journal of Comparative Pathology, 152 (1). p. 79. ISSN 0021-9975 DOI: https://doi.org/10.1016/j.jcpa.2014.10.153

Link to Leeds Beckett Repository record:

https://eprints.leedsbeckett.ac.uk/id/eprint/6128/

Document Version:

Article (Accepted Version)

Creative Commons: Attribution-Noncommercial-No Derivative Works 4.0

The aim of the Leeds Beckett Repository is to provide open access to our research, as required by funder policies and permitted by publishers and copyright law.

The Leeds Beckett repository holds a wide range of publications, each of which has been checked for copyright and the relevant embargo period has been applied by the Research Services team.

We operate on a standard take-down policy. If you are the author or publisher of an output and you would like it removed from the repository, please contact us and we will investigate on a case-by-case basis.

Each thesis in the repository has been cleared where necessary by the author for third party copyright. If you would like a thesis to be removed from the repository or believe there is an issue with copyright, please contact us on openaccess@leedsbeckett.ac.uk and we will investigate on a case-by-case basis. 


\section{Pilot study with a murine model to further dissect the pathogenesis of japanese encephalitis.}

Ricci, E and Galbraith, SE and Kipar, A (2015)

Introduction: Japanese encephalitis virus (JEV) is a neurotropic flavivirus transmitted by Culex spp. mosquitoes and responsible for life-threatening encephalitides in man and animals in east and south Asia. To fully reveal the pathogenesis of Japanese encephalitis (JE) in man, reproducible and comparable animal models are needed. Here we describe the neuropathological findings of a pilot study to assess the validity of a mouse model using intraperitoneal infection.

Materials and Methods: Six 10-month-old female C57BL/6 mice were inoculated intraperitoneally with a single dose of JEV (JEV P3 strain); a further four received PBS (controls). Animals were killed after 10 days, when clinical signs developed. Brains were fixed in formalin and embedded in paraffin wax. A detailed histopathological examination was performed and immunohistology for the demonstration of viral antigen, astrocytes (GFAP), microglia (Iba1), iNOS and apoptotic cells (cleaved caspase-3) undertaken.

Results: Infected animals exhibited severe non-suppurative encephalitis, affecting the cerebrum and thalamus and characterized by lymphocyte-rich perivascular cuffs and vigorous microglial and astrocyte proliferation/activation. Viral antigen was detected in both intact and cleaved caspase-3 positive apoptotic neurons. Iba1-positive microglial cells exhibited strong iNOS co-expression. 